\title{
Diet of benthivorous fish and prey availability in streams of the Pirapó River basin-PR
}

\author{
Dieta de peixes bentívoros e disponibilidade de presa em riachos da bacia do rio Pirapó-PR
}

\author{
Renata Guglielmetti $^{1}$ (D), Marlene Rodrigues Silva ${ }^{1 *}$ (D), Janet Higuti ${ }^{1,2}$ (D), Rosemara Fugi ${ }^{1,2}$ (D)
}

\author{
${ }^{1}$ Programa de Pós-graduação em Ecologia de Ambientes Aquáticos Continentais - PEA, \\ Universidade Estadual de Maringá - UEM, Av. Colombo, 5790, Jardim Universitário, \\ Bloco G-90, CEP 87020-900, Maringá, PA, Brasil \\ ${ }^{2}$ Núcleo de Pesquisas em Limnologia, Ictiologia e Aquicultura - NUPÉLIA, Universidade Estadual \\ de Maringá - UEM, Av. Colombo, 5790, Jardim Universitário, Bloco G-90, CEP 87020-900, \\ Maringá, PA, Brasil \\ *e-mail: marlenersbio@gmail.com
}

Cite as: Guglielmetti, R. et al. Diet of benthivorous fish and prey availability in streams of the Pirapó River basin-PR. Acta Limnologica Brasiliensia, 2019, vol. 31, e7.

\begin{abstract}
Aim: This study aimed to investigate the diet of seven species of fish that consume predominantly benthic macroinvertebrates, and the availability of these organisms in the environment. We analyzed the occurrence of trophic segregation between species and the correlation between the abundance of macroinvertebrates in the diet and in the environment. Methods: Fish and macroinvertebrates were sampled in three streams of the Pirapó River basin (Upper Paraná River - Brazil). Differences in diet composition between species were tested using a multivariate permutation analysis of variance (PERMANOVA). A Spearman Correlation was performed to test the relation between the abundance the macroinvertebrates consumed and those available in the environment. Results: All species mainly consumed aquatic insect, and significant interspecific variations in diet composition were found for most of them. For five out of the seven species of fish analyzed no significant correlation was detected between the abundance of macroinvertebrates in the environment and in the diet. Conclusions: The results showed that most of the species segregate and their diets are not positively correlated with the abundance of preys in the environment, indicating that the most consumed macroinvertebrates were not the most abundant in the environment. These results suggest that the fish species select the macroinvertebrates, and that the morphological and behavioral characteristics of both predators and prey are important in feeding fish from streams.
\end{abstract}

Keywords: trophic segregation; macroinvertebrate availability; benthic fauna; Upper Paraná River.

Resumo: Objetivo: O objetivo deste estudo foi avaliar a dieta de sete espécies de peixes que consomem predominantemente macroinvertebrados bentônicos, e a disponibilidade desses organismos no ambiente. Foi analisada a ocorrência de segregação trófica entre as espécies de peixes e a correlação entre a abundância de macroinvertebrados na dieta e no ambiente. Métodos: Peixes e macroinvertebrados foram amostrados em três riachos da bacia do Rio Pirapó (alto Rio Paraná Brasil). Diferenças na composiçâo da dieta entre as espécies foram testadas usando uma análise de variância permutacional multivariada (PERMANOVA). Foi utilizada uma correlaçáo de Spearman para testar a relação entre a abundância de macroinvertebrados consumidos e os disponíveis no ambiente. Resultados: Todas as espécies consumiram predominantemente insetos aquáticos, mas variaçôes interespecíficas significativas na composição da dieta foram verificadas para a maioria delas. Para cinco das sete espécies analisadas não houve correlação significativa entre a abundância 
de macroinvertebrados na dieta e os disponíveis no ambiente. Conclusóes: Os resultados mostraram que houve segregação trófica entre a maioria das espécies, e que suas dietas não foram correlacionadas positivamente com a abundância de presas no ambiente, indicando que os macroinvertebrados mais consumidos não foram os mais abundantes no ambiente. Estes resultados sugerem que as espécies selecionam os macroinvertebrados e que características morfológicas e comportamentais de ambos predadores e presas são importantes na alimentação de peixes de riachos.

Keywords: segregação trófica; disponibilidade de macroinvertebrados; fauna bentônica; Alto rio Paraná.

\section{Introduction}

The optimal diet of a predator is considered to be the positive balance between the energy spent in the search and capture of the prey and the energy obtained in its consumption (MacArthur \& Pianka, 1966), and this concept is used in the attempt to explain patterns in the use of food resources. Most predators consume a variety of prey lower than those potentially available in the environment (Colwell \& Futuyma, 1971), and diet composition is often associated with the abundance and nutritional quality of the prey (Griffiths, 1975; Cantanhêde et al., 2009), and to the morphological and behavioral traits of predator and prey (O’Brien, 1979; Worischka et al., 2015; Rodríguez-Lozano et al., 2016). For fish, the predator-prey relationship, with respect to food preference, seems to vary between species with different feeding habits, for piscivorous and zooplanctivorous fish, for example, the diet is mainly associated with the abundance and size of prey (Cantanhêde et al., 2009; Lopez Cazorla et al., 2011). For benthivorous fish, particularly from streams, the effect of these factors on the predator-prey relationship is unclear, which may be associated with the fact that these fishes dwell the bottom, a structurally complex habitat not always accessible to fish (Hill \& Grossman, 1987) which prevents many prey from being used by predators (Gillette, 2012). Recent studies show that many species that consume benthic invertebrates have well-defined diets (Melo et al., 2004; Silva et al., 2012; Cruz et al., 2013; Soares et al., 2017), and the use of certain dietary resources is mainly attributed to the trophic morphology and feeding strategies of predators (Rolla et al., 2009; Silva et al., 2012; Brejão et al., 2013; Neves et al., 2015).

Feeding strategies of fish that consume benthic invertebrates in streams are complex because, in addition to the morphological and behavioral characteristics of predators, prey varies in morphology, mobility and behavioral characteristics, which makes it difficult to evaluate the cost and benefit of selecting a particular prey
(Gillette, 2012). Unlike fish that consume food resources drift, which are usually visual predators, small benthivorous fish usually feed at night and may use other morphological features to capture their prey (Worischka et al., 2015). The benthic macroinvertebrates community is composed of individuals with sessile or mobile habits, living on submerged substrates (Uieda \& Ramos, 2007) and distributed according to the physical conditions of the environment and the availability of food (Merritt \& Cummins, 1984). Streams have a highly-diversified macroinvertebrate fauna, represented by several phyla, such as Arthropoda, Mollusca, Annelida, Nematoda and Platyhelminthes (Melo \& Froehlich, 2001). Among these groups, the class Insecta has the highest abundance and number of species (Allan, 1995; Buckup et al., 2007; Rezende et al., 2011).

Although several studies have been conducted on the diet of benthivorous fish in Neotropical streams, information on the availability of food resources in the environment is still scarce, and usually evaluates only one species. This study aimed to investigate the diet of seven species of fish that consume predominantly benthic invertebrates, and the availability of these organisms in the environment. Considering that differences in the use of microhabitats, trophic morphology and feeding strategies of benthivorous stream predators may be responsible for the differential use of food resources (Silva et al., 2012; Brejão et al., 2013; Neves et al., 2015) and that these predators consume fewer prey than potentially available in the environment (Colwell \& Futuyma, 1971), we hypothesize that trophic segregation occurs between benthivorous species, and we asked two questions: (i) Is there difference in diet composition between the species? (ii) Is there correlation between macroinvertebrates consumed and those available in the environment? To answer these questions, we used data of fish and macroinvertebrates collected in three low-order streams belonging to the Pirapó River basin, Upper Paraná River. 


\section{Materials and Methods}

Fish and macroinvertebrates were sampled in three low-order streams ( $<3$ rd order -Água Queçaba, Remo and Zaúna), located in the Pirapó River basin - Paraná State (Upper Paraná River) in the physiographic region termed the Terceiro Planalto Paranaense (Third Plateau of Paraná; $22^{\circ} 30^{\prime}-23^{\circ} 30^{\prime} \mathrm{S}$ and $\left.51^{\circ} 15^{\prime}-52^{\circ} 15^{\prime} \mathrm{W}\right)$ with a drainage area of $c .5076 \mathrm{~km}^{2}$ (Cunico et al., 2012). Rainy season commonly occur in summer (average annual 1500 to $1600 \mathrm{~mm}$ ), with annual average temperatures $>20{ }^{\circ} \mathrm{C}$. In order to characterize the sampled streams, measurements of width, depth, water velocity (using an electronic flowmeter), dominant substrate of the bed, dominant riparian vegetation and soil use (Table 1 ).

Fish were sampled bimonthly from July 2007 to June 2008 from three equidistant segments of each stream. Electrofishing equipment $(1 \mathrm{~kW}$, 220 V, 3-4 A portable AC generator) was used, with a procedure of three successive catches with a constant unit of effort. All specimens were anaesthetized with eugenol and fixed in $4 \%$ formaldehyde. Fish were identified, measured (standard length, SL, cm) and their stomachs were removed for analysis. Voucher specimens were deposited in the Fish Collection of Núcleo de Pesquisas em Limnologia, Ictiologia e Aquicultura (Nupélia), State University of Maringá (Paraná State, Brazil) (UEM, 2018). Macroinvertebrates benthic were sampled in the same stretches in July 2007 and February 2008, using a Surber sampler $\left(0.09 \mathrm{~m}^{2}\right)$ with a mesh size of $0.250 \mathrm{~mm}$. In each stretch, three samples were collected and fixed in the field with formaldehyde $4 \%$ buffered with calcium carbonate. The macroinvertebrates were sorted under a stereomicroscope, identified with the assistance of specialized literature, and counted. Taxa with relative abundance less than $0.5 \%$ was grouped in the category other invertebrates. The abundance of macroinvertebrates in the environment was expressed as number of individuals $/ \mathrm{m}^{2}$.
In this study were analyzed individuals belonging to seven fish species: Characidium aff. zebra Eigenmann 1909 (2.7-6.5 cm;n=69), Cetopsorhamdia iheringi Schubart \& Gomes 1959 (3.8-9.0 cm; $n=27$ ), Gymnotus inaequilabiatus (Valenciennes 1836) $(6.5-12.3 \mathrm{~cm} ; n=25)$, Imparfinis borodini Mees \& Cala $1989(3.2-12.5 \mathrm{~cm} ; n=12)$, Imparfinis mirini Haseman $1911(\mathrm{SL}=2.5-7.9 \mathrm{~cm}$; $n=17)$, Phenacorhamdia tenebrosa (Schubart 1964) (3.1-7.0 cm; $n=6)$ and Trichomycterus diabolus (Bockmann, Casatti \& Pinna 2004) (1.7-6.4 cm; $n=6)$. For diet analysis, food items were identified and quantified by the volumetric method using a glass counting plate (Hellawell \& Abel, 1971).

Principal Coordinates Analysis (PCoA) was used to summarize the diet data in each stream. Differences in diet composition among species were tested using a multivariate permutation analysis of variance (PERMANOVA - Anderson, 2005), which was applied to a matrix of food items of individual fish, with volume values log transformed. For all multivariate analyses, was used the Bray-Curtis dissimilarity as a measure of distance with transformed data obtained from 9999 random permutations. All statistical analyses were conducted in the R Programming Environment using the Vegan package (R DEVELOPMENT CORE TEAM, 2018) A Spearman Correlation was performed to test the relation between the abundance the macroinvertebrates consumed and those available in the environment. Values of $\mathrm{p}<0.05$ indicate significant correlations. This analysis was performed in the Statistica 7.0 software (STATSOFT, 2005). Spearman Correlation was performed per species and stream. The same taxonomic resolution was used for the available and consumed preys.

\section{Results}

The ordination of the diet data of the individuals collected in the Água Queçaba stream indicated species separation (Figure 1). The most distinct species was $C$. iheringi, which consumed almost exclusively Simuliidae larvae $(94.4 \%$ of the

Table 1. Environmental characteristics at three streams of the sub-basin of the Pirapó River, upper Paraná River basin (mean values).

\begin{tabular}{cccc}
\hline & Água Queçaba & Remo & Zaúna \\
\hline Width $(\mathrm{m})$ & 2.50 & 2.57 & 1.77 \\
Depth $(\mathrm{m})$ & 0.24 & 0.20 & 0.17 \\
Velocity $(\mathrm{m} / \mathrm{s})$ & 0.22 & 0.20 & 0.16 \\
Dominant Substrate & clay/sand & clay/sand & clay/sand \\
Dominant Vegetation & shrub & shrub & shrub \\
Use of the soil & agriculture and pasture & agriculture and pasture & agriculture and pasture \\
\hline
\end{tabular}


diet - Figure 1) whose diet was significantly different from the diet of all other species (Table 2). G. inaequilabiatus was the only one that consumed Tipulidae larvae (36.6\%) and I. borodini consumed high amounts aquatic Coleoptera (59\%), but both were the only ones that consumed high amounts of Odonata $(29.0 \%$ and $24.4 \%$, respectively - Figure 1). Phenacorhamdia tenebrosa was distinct from the other species and its diet was composed mainly of Trichoptera larvae $59 \%$ of the diet - Figure 1). The diet of I. mirini differed significantly from all other species, a result of the high consumption of Isoptera, which represented $32 \%$ of the diet (Figure 1). According to the ordination analysis, the diet of C. zebra, composed mainly of Trichoptera (37\%), Chironomidae (29\%) and Ephemeroptera (16\%) was grouped with other
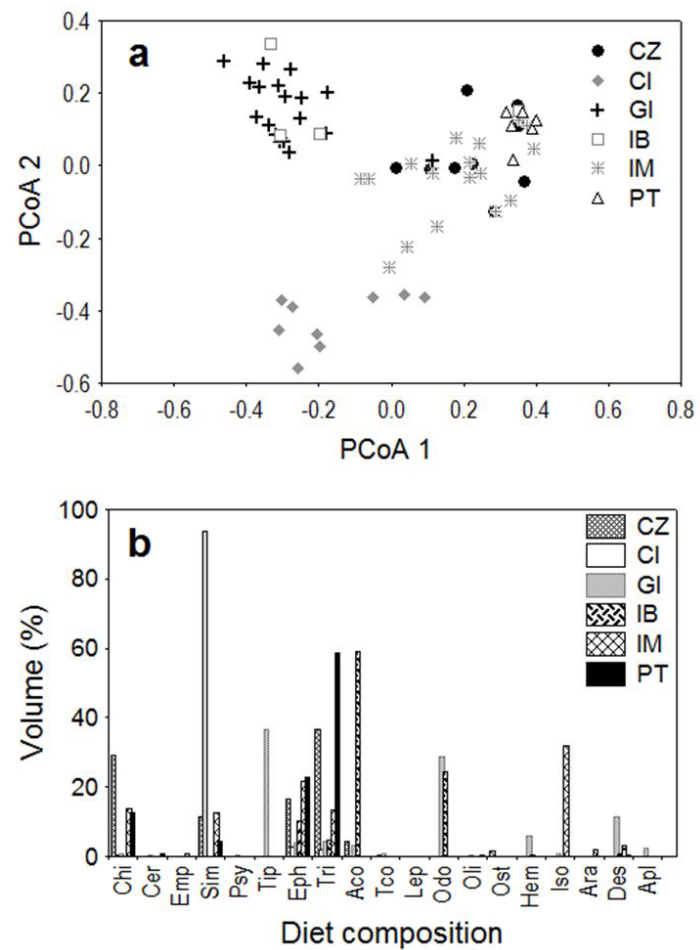

Figure 1. Diet data ordination (using the first two axes of PCoA, that explained $29 \%$ of the data variance) (a), and diet composition (b) of fish species sampled in the Água Queçaba stream. $\mathrm{CZ}=$ C. zebra; $\mathrm{CI}=C$. iheringi; $\mathrm{GI}=G$. inaequilabiatus; $\mathrm{IB}=I$. borodini; $\mathrm{IM}=$ I. mirini $\mathrm{PT}=$ P. tenebrosa $\mathrm{Chi}=$ Chironomidae; Cer = Ceratopogonidae; Emp = Empididae; Sim = Simuliidae; Psy= Psychodidae; Tip= Tipulidae; Eph= Ephemeroptera; Tri $=$ Trichoptera; Aco $=$ aquatic Coleoptera; $\mathrm{Tco}=$ terrestrial Coleoptera; Lep= aquatic Lepidoptera; Odo= Odonata; Oli= Oligochaeta; Ost $=$ Ostracoda; Hem = Hemiptera; Iso= Isopoda; Ara $=$ Araneae; Des $=$ detritus $/$ sediment Apl= aquatic plants. species. PERMANOVA showed that of the 15 pairs of species tested in the Água Queçaba, 12 presented significant differences in the diet (Table 2).

The results of the ordination analysis of the three species in the Remo stream showed the separation of $G$. inaequilabiatus from the other species, a result of the high consumption of Odonata $(54 \%$ of the diet) (Figure 2). There was an overlap in the diet of C. zebra and T. diabolus, which consumed similar proportions of Ephemeroptera, Trichoptera and Chironomidae (Figure 2). PERMANOVA indicated that the diet of $G$. inaequilabiatus was significantly different from that of the other two species, whereas there was no significant difference between C. zebra and T. diabolus (Table 2).

In the Zaúna stream, the ordination of the diet data showed the separation of the three species and separation between the individuals of C. zebra (Figure 3 ). The most consumed item by $C$. iheringi was Simuliidae (36\% of the diet), by I. borodini Odonata (51\%), and by C. zebra Amphipoda (42\%) and Trichoptera larvae (26\%) (Figure 3).

Table 2. Results of permutational multivariate analysis of variance (PERMANOVA) applied to diet data of fish species sampled in three streams located in the Pirapó River basin (Upper Paraná River, Brazil).

\begin{tabular}{|c|c|}
\hline Stream/Species & PERMANOVA \\
\hline Água Queçaba & $\begin{array}{c}\text { Pseudo- } F_{1,63}=5.04 ; \\
p=0.001\end{array}$ \\
\hline C. zebra x C. iheringi & $p<0.001$ \\
\hline C. zebra $\times$ G. inaequilabiatus & $p<0.001$ \\
\hline C. zebra x I. mirini & $p=0.04$ \\
\hline C. zebra x P. tenebrosa & $p=0.164$ \\
\hline C. zebra x I. mirini & $p=0.085$ \\
\hline C. iheringi x G. inaequilabiatus & $p<0.001$ \\
\hline C. iheringi $x$ I. borodini & $p<0.001$ \\
\hline C. iheringi $x$ P. tenebrosa & $p<0.001$ \\
\hline C. iheringi $x$ I. borodini & $p=0.002$ \\
\hline G. inaequilabiatus $\times$ I. mirini & $p<0.001$ \\
\hline G. inaquilabiatus $\times$ P. tenebrosa & $p<0.001$ \\
\hline G. inaequilabiatus $\times$ I. borodini & $p=0.44$ \\
\hline I. mirini $\times$ P. tenebrosa & $p<0.01$ \\
\hline I. mirini x I. borodini & $p<0.01$ \\
\hline P. tenebrosa $\times$ I. borodini & $p=0.021$ \\
\hline Remo & $\begin{array}{c}\text { Pseudo- } F_{1,39}=5.75 ; \\
p=0.0002\end{array}$ \\
\hline C. zebra x G. inaequilabiatus & $p=0.002$ \\
\hline C. zebra x T. diabolus & $p=0.824$ \\
\hline G. inaequilabiatus $\times$ T. diabolus & $p=0.004$ \\
\hline Zaúna & $\begin{array}{c}\text { Pseudo- } F_{1},{ }_{57}=6.70 ; \\
p=0.0002\end{array}$ \\
\hline C. zebra x C. iheringi & $p=0.002$ \\
\hline C. zebra x I. borodini & $p=0.002$ \\
\hline C. iheringi x I. borodini & $p=0.002$ \\
\hline
\end{tabular}


PERMANOVA evidenced a significant difference between the three species analyzed (Table 2).

A total of 7,163 macroinvertebrates individuals were collected in Água Queçaba stream, belonging to 21 taxa, the most abundant were Chironomidae, Ephemeroptera, Trichoptera, Oligochaeta and Coleoptera, which together represented $82 \%$ of the collected individuals (Figure 4a). Twenty-six taxa were recorded in the Remo stream, totaling 4,300 individuals, with Chironomidae, Ostracoda, Coleoptera, Ephemeroptera and Oligochaeta accounting for $80 \%$ of the individuals sampled (Figure 4b). A total of 5,849 macroinvertebrates individuals were collected in Zaúna stream, belonging to 20 taxa, with an expressive abundance of Ephemeroptera (36.37\%), followed by Coleoptera, Ostracoda and Trichoptera (Figure 4c).
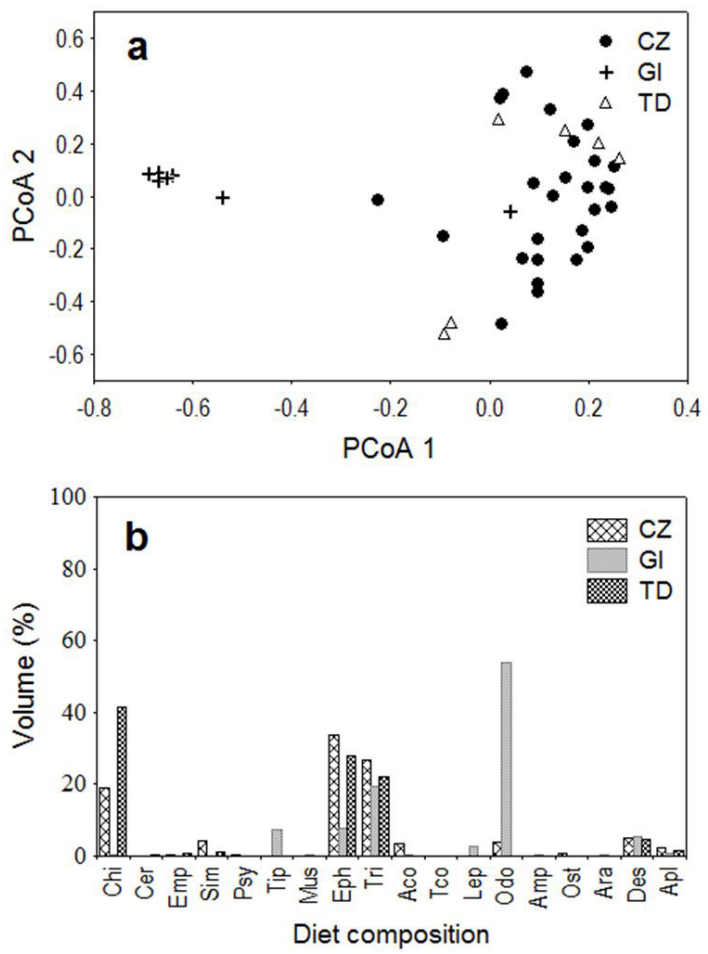

Figure 2. Diet data ordination (using the first two axes of PCoA, that explained $42 \%$ of the data variance) (a) and diet composition (b) of fish species sampled in the Remo stream. $\mathrm{CZ}=C$. zebra; $\mathrm{GI}=G$. inaequilabiatus; $\mathrm{TD}=T$. diabolus; Chi= Chironomidae; Cer $=$ Ceratopogonidae; Emp = Empididae; Sim = Simuliidae; Psy= Psychodidae; Tip= Tipulidae; Mus= Muscidae $;$ Eph $=$ Ephemeroptera $;$ Tri $=$ Trichoptera; Aco $=$ aquatic Coleoptera; $\mathrm{Tco}=$ terrestrial Coleoptera; Lep = aquatic Lepidoptera; Odo= Odonata; Amp = Amphipoda; Ost $=$ Ostracoda; Ara= Araneae; Des= detritus/sediment; Apl= aquatic plants.
Significant positive correlations between the abundance of macroinvertebrates in the environment and in the diet were detected only for C. zebra and P. tenebrosa in all the streams where these species occurred (Table 3 ). In addition, this species consumed a high amount of Amphipoda in the Zaúna stream (Figure 3b), a crustacean whose abundance was expressive only in this stream (Figure 4c). The correlation between the abundance of macroinvertebrates in the environment and the diet of P. tenebrosa was recorded mainly for Trichoptera, the item most consumed by this species (Figure 1a) and one of the most abundant in the Água Queçaba stream, where the species occurred (Figure 4a). However, for most species (C. iheringi, I. borodini, I. mirini, G. inaequilabiatus and $T$. diabolus) no significant correlation was observed (Table 3).
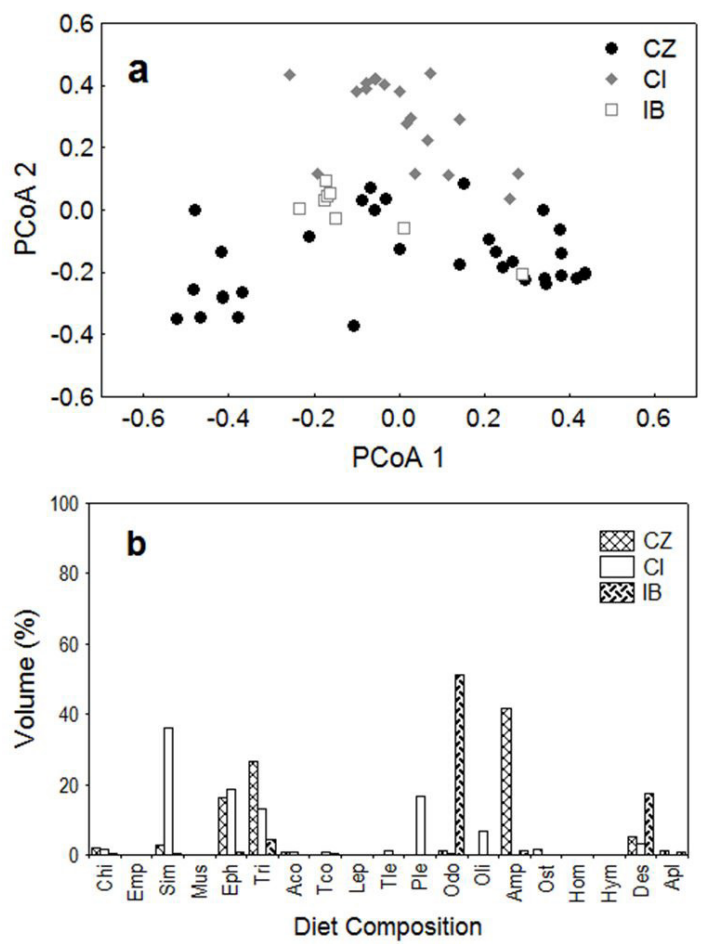

Figure 3. Diet data ordination (using the first two axes of PCoA that explained $34 \%$ of the data variance) (a) and diet composition (b) of fish species sampled in the Zaúna stream. $\mathrm{CZ}=C$. zebra; $\mathrm{CI}=C$. iheringi; $\mathrm{IB}=I$. borodini; Chi= Chironomidae; $\mathrm{Emp}=$ Empididae; $\mathrm{Sim}=$ Simuliidae; Mus= Muscidae; Eph= Ephemeroptera; Tri $=$ Trichoptera; Aco $=$ Aquatic Coleoptera; $\mathrm{Tco}=$ terrestrial Coleoptera; Lep = aquatic Lepidoptera; Tle = terrestrial Lepidoptera; $\mathrm{Ple}=$ Plecoptera; Odo= Odonata; Oli $=$ Oligochaeta; Amp = Amphipoda; Ost = Ostracoda Hom = Homoptera; Hym = Hymenoptera; Des = detritus/sediment; Apl= aquatic plants. 

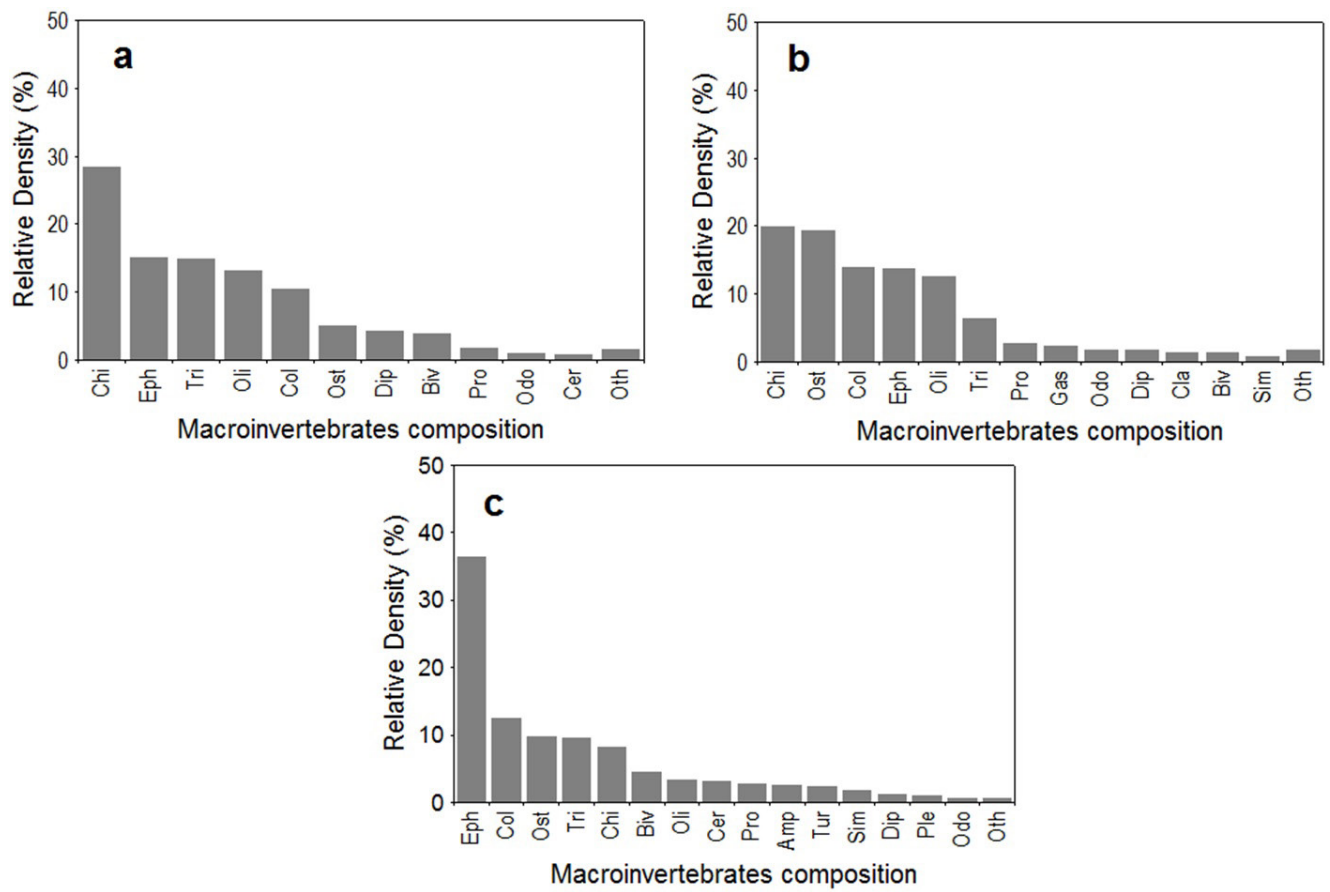

Figure 4. Relative abundance of aquatic macroinvertebrates sampled in Água Queçaba stream (a), Remo stream (b) and Zaúna stream (c). Chi= Chironomidae; Cer= Ceratopogonidae; $\mathrm{Sim}=$ Simuliidae; Dip= Diptera; Eph= Ephemeroptera; Tri $=$ Trichoptera; $\mathrm{Col}=$ Coleoptera; $\mathrm{Ple}=$ Plecoptera; Odo $=$ Odonata; Oli $=$ Oligochaeta; Ost $=$ Ostracoda; $\mathrm{Amp}=$ Amphipoda; Biv= Bivalvia; Pro= Prostigmata; Tur $=$ Turbellaria; $\mathrm{Cla}=$ Cladocera; Gas $=$ Gastropoda; Oth= others invertebrates.

Table 3. Results of Spearman correlation $(R)$ between abundance of prey in the environment and diet of fish species sampled in three streams located in the Pirapó River sub-basin (Paraná River, Brazil).

\begin{tabular}{lll}
\hline \multicolumn{1}{c}{ Stream/Species } & & $\boldsymbol{R}$ \\
\cline { 1 - 1 } \multicolumn{1}{c}{ Água Queçaba } & & $\boldsymbol{p}$ \\
C. zebra & 0.68 & $0.01^{*}$ \\
C. iheringi & 0.26 & 0.42 \\
G. inaequilabiatus & 0.09 & 0.73 \\
l. borodini & 0.25 & 0.42 \\
l. mirini & 0.55 & 0.07 \\
P. tenebrosa & 0.62 & $0.04^{*}$ \\
\hline \multicolumn{1}{c}{ Remo } & & \\
\hline C. zebra Zaúna & 0.69 & $0.01^{*}$ \\
G. inaequilabiatus & 0.05 & 0.85 \\
T. diabolus & 0.38 & 0.19 \\
\hline \multicolumn{1}{c}{ C. zebra } & & \\
C. iheringi & 0.63 & $0.01^{*}$ \\
I. borodini & 0.45 & 0.14 \\
& 0.42 & 0.14
\end{tabular}

*Significant correlation.

\section{Discussion}

The seven species analyzed mainly consumed aquatic macroinvertebrates represented basically by immature forms of insects, which is associated to the high abundance and richness of these organisms in the studied streams and observed in others studies (Allan, 1995; Buckup et al., 2007; Rezende et al., 2011; Cunha et al., 2014). Although all species have consumed insects, interspecific differences in diet were recorded for most of them, evidencing the trophic segregation and the differential use of the available resources in the environment. The use of several sites to evaluate the diet of the species increases the variation of the available food items allowing the identification of food preferences (Asanka et al., 2015). In this context, our results showed that for most of the studied species the main food items were in general the same in the streams where they occurred, suggesting that the species have preference for some macroinvertebrates regardless of the studied stream. The lack of correlation between the abundance of prey in the diet and in the environment, for five of the seven species studied, reinforces the hypothesis that these predators have a food preference, which depends largely on the morphological and behavioral traits of both predator and prey (O'Brien, 1979; Worischka et al., 2015; Rodríguez-Lozano et al., 2016).

The food preference of $G$. inaequilabiatus and I. borodini was Odonata larvae, which was not 
abundant in the environment, is probably associated with the behavior of these predators and its prey. Souza et al. (2015) evaluated the influence of habitat structuring on the distribution of Odonata in several Neotropical streams, including the streams studied here. These authors observed that the occurrence of some species was associated with microhabitats with greater leaf biomass in the substrate, used as a local of refuge and larval development (Merritt \& Cummins, 1984). This should make it difficult to consume these preys, and only predators with feeding strategies capable of detecting these preys can be successful. This appears to be the case of $G$. inaequilabiatus, a representative of the order Gymnotifomes characterized by fish that capture their prey near the substrate using electrical sensory organs to detect them (Brejão et al., 2013). This association can also be made for I. borodini, because species of the genus Imparfinis speculate the substrate and use the sensory function of the head barbels to find and capture the preys (Casatti, 2002; Casatti \& Castro, 2006)

Cetopsorhamdia iheringi mainly consumed Simuliidae larvae, although these invertebrates did not show high availability in the environment. The low abundance of Simuliidae in the samplings may be because these invertebrates have structures in the abdomen that allow their attachment to several substrates, mainly rocks (McCafferty, 1981; Thorp \& Covich, 2010), which probably hindered their sampling. However, water flow can displace the larvae causing them to drift (Elliott, 2008), as observed by Gimenez et al. (2015), which recorded high density of these larvae drifting in Neotropical streams. Thus, the high consumption of Simuliidae may be associated to the fact that these larvae are attached to rocks, and because $C$. iheringi presents slender body, well developed sensory barbels and dorsal eyes, characteristics that help the exploration of small spaces between the bottom rocks (Casatti \& Castro, 2006), facilitating the detection and capture of these larvae.

Larvae of Chironomidae, Trichoptera and Ephemeroptera were recorded in the diet of all species in all streams, and were important for four of them in different proportions, resulting in interspecific differences. These insects, in general, were the most abundant in the streams studied here, as well as in other streams where they had high abundances in the substrate and drifting (Bagatini et al., 2012; Gimenez et al., 2015). Trichoptera and Ephemeroptera were the items most consumed by $I$. mirini, and also the most abundant in the environment which make them easily captured prey, mainly by species of the genus Imparfinis, considered speculators of the substrate, since they use the head barbels to find and capture the prey in the substrate (Casatti \& Castro, 2006); Isopoda was also a resource explored by $I$. mirini, being important only for this species. The terrestrial origin of this resource (Isopoda) suggests that this species uses, in addition to benthic macroinvertebrates, food resources drifting.

Chironomidae larva was the macroinvertebrate most consumed by $T$. diabolus and also the most abundant in the Remo stream, where the species occurred. In many streams, these larvae have been recorded among the most abundant (Chará et al., 2006; Bagatini et al., 2012), and several species of Trichomycterus presented a high correlation between consumption of Chironomidae larvae and their abundance in the environment (Chará et al., 2006), which is probably associated with the high protein value and digestibility of these macroinvertebrates (Armitage et al., 1995). Species of the genus Trichomycterus are considered nocturnal predators that swim rapidly looking for small prey near the bottom, and during the day they remain buried in the substrate, usually muddy or sandy (Chará et al., 2006; Brejão et al., 2013). This behavior may have facilitated the consumption of Chironomidae larvae by $T$. diabolus, once these macroinvertebrates prefer fine substrates, such as sand and mud (Chará et al., 2006). Nonetheless, there was no correlation between prey abundance in the diet of T. diabolus and in the environment, probably due to the important consumption of Ephemeroptera and Trichoptera, less abundant invertebrates in the Remo.

Unlike the species described above, C. zebra and $P$. tenebrosa showed a positive correlation between the abundance of prey in the diet and in the environment, indicating that the resources most consumed by these species were also the most abundant in the environment. For C. zebra, Ephemeroptera, Chironomidae and Trichoptera were the most important food items and also abundant in streams; however, in the Zaúna stream, the diet was mainly composed of Amphipoda, where there was the greatest abundance of this crustacean. Bastos et al. (2013) also found Amphipoda as an important food item for Characidium rachovii. These crustaceans are associated with habitats with higher water flow (Moya et al., 2009), as well as some Ephemeroptera and Trichoptera (Baptista et al., 2001).The fact that Characidium has a fusiform 
body and pectoral and pelvic fins enlarged in the ventral position allows individuals to remain close to the substrate resisting the flow of water (Aranha et al., 2000), and to quickly attack nearby prey (Brejão et al., 2013), which may facilitate the capture of macroinvertebrates colonizing environments with higher flow, such as Amphipoda.

Although several species have consumed Trichoptera, only the diet of P. tenebrosa was dominated by these macroinvertebrates, which were abundant in the sites where the species occurred, and are considered easy-capture prey due to the low mobility (Tófoli et al., 2013). Little information is available for the genus Phenacorhamdia; Casatti (2002) classified $P$. hohenei as a substrate-speculating nocturnal species, which has as its preferential substrate rocky and macrophyte roots, and Ferreira (2007) showed that $P$. tenebrosa consumes aquatic invertebrates, and its preferential habitat is rocky bottom with high current flow.

Our results showed that all the analyzed species fed on benthic macroinvertebrates, nevertheless, interspecific differences in diet composition were found for most species. For example, the food items most consumed by $G$. inaequilabiatus, $C$. iheringi, T. diabolus and $P$. tenebrosa were aquatic insects represented by Odonata, Simuliidae, Chironomidae and Trichoptera, respectively, indicating the occurrence of trophic segregation between them. Moreover, for five of the seven species analyzed, the abundance of prey in the diet was not positively correlated with the abundance of prey in the environment, evidencing the importance of the morphological and behavioral characteristics of both predators and prey in feeding Neotropical stream fish.

\section{References}

ALLAN, J.D. Stream ecology: structure and function of running waters. London: Hall \& Chapman, 1995. http://dx.doi.org/10.1007/978-94-011-0729-7.

ANDERSON, M.J. PERMANOVA: a FORTRAN computer program for permutational multivariate analysis of variance. Auckland: Department of Statistics, University of Auckland, 2005.

ARANHA, J.M.R., GOMES, J.H.C. and FOGAÇA, N.O. Feeding of two sympatric species of Characidium, C. lanei and C. pterostictum (Characidiinae) in a coastal stream of Atlantic Forest (Southern Brazil). Brazilian Archives of Biology and Technology, 2000, 43(5), 527-531. http://dx.doi.org/10.1590/S151689132000000500013

ARMITAGE, P.D., CRANSTON, P.S. and PINDER, L.C.V. The Chironomidae: biology and ecology of non-biting midges. London: Chapman \& Hall, 1995. http://dx.doi.org/10.1007/978-94-011-0715-0.

ASANKA, U., JAYASINGHE, D., GARCIABERTHOU, E., LI, Z., LI, W., ZHANG, T. and LIU, J. Co-occurring bighead and silver carps show similar food preference but different isotopic niche overlap in different lakes. Environmental Biology of Fishes, 2015, 98(4), 1185-1199. http://dx.doi. org/10.1007/s10641-014-0351-7.

BAGATINI, Y.M., DELARIVA, L. and HIGUTI, J. Benthic macroinvertebrate community structure in a stream of the north-west region of Paraná State, Brazil. Biota Neotropica, 2012, 12(1), 307-317. http:// dx.doi.org/10.1590/S1676-06032012000100023.

BAPTISTA, D.F., BUSS, D.F., DORVILLÉ, L.F.M. and NESSIMIAN, J.L. Diversity and habitat preference of aquatic insects along the longitudinal gradient of the Macaé river basin, Rio de Janeiro, Brazil. Revista Brasileira de Biologia, 2001, 61(2), 249-258. http:// dx.doi.org/10.1590/S0034-71082001000200007. PMid:11514892.

BASTOS, R., MIRANDA, F.S. and GARCIA, A.M. Dieta e estratégia alimentar de Characidium rachovii (Characiformes, Crenuchidae) em riachos de planície costeira do sul do Brasil. Iheringia. Série Zoologia, 2013, 103(4), 335-341. http://dx.doi.org/10.1590/ S0073-47212013000400001.

BREJÃO, G.L., GERHARD, P. and ZUANON, J. Functional trophic composition of the ichthyofauna of forest streams in eastern Brazilian Amazon. Neotropical Ichthyology, 2013, 11(2), 361-373. http:// dx.doi.org/10.1590/S1679-62252013005000006.

BUCKUP, L., BUENO, A.A.P., BOND-BUCKUP, G., CASAGRANDE, M. and MAJOLO, F. The benthic macroinvertebrate fauna of highland streams in southern Brazil: composition, diversity and structure. Revista Brasileira de Zoologia, 2007, 24(2), 294-301. http://dx.doi.org/10.1590/S010181752007000200005

CANTANHÊDE, G., FUGI, R. and HAHN, N.S. Variation in prey selection of a piscivorous fish after the impoundment of a Neotropical reservoir: prey size and type. Journal of Fish Biology, 2009, 75(1), 75-86. http://dx.doi.org/10.1111/j.10958649.2009.02264.x. PMid:20738483.

CASATTI, L. Alimentação dos peixes em um riacho do parque estadual Morro do Diabo, bacia do alto rio Paraná, sudeste do Brasil. Biota Neotropica, 2002, 2(2), 1-14. http://dx.doi.org/10.1590/S167606032002000200012.

CASATTI, L. and CASTRO, R.M.C. Testing the ecomorphological hypothesis in a headwater riffles fish assemblage of the Rio São Francisco, southeastern Brazil. Neotropical Ichthyology, 2006, 4(2), 203-214. http://dx.doi.org/10.1590/S167962252006000200006 . 
CHARÁ, J.D., BAIRD, D.J., TELFER, T.C. and RUBIO, E.A. Feeding ecology and habitat preferences of the catfish genus Trichomycterus in low-order streams of the Colombian Andes. Journal of Fish Biology, 2006, 68(4), 1026-1040. http://dx.doi. org/10.1111/j.0022-1112.2006.00984.x.

COLWELL, R.K. and FUTUYMA, D.J. On the measurement of niche breadth and overlap. Ecology, 1971, 52(4), 567-576. http://dx.doi. org/10.2307/1934144. PMid:28973805.

CRUZ, B.B., TESHIMA, F.A. and CETRA, M. Trophic organization and fish assemblage structure as disturbance indicators in headwater streams of lower Sorocaba River basin, São Paulo, Brazil. Neotropical Ichthyology, 2013, 11(1), 171-178. http://dx.doi. org/10.1590/S1679-62252013000100020.

CUNHA, J.C.S, BARROS-FILHO, R.G., SILVA, R.P., SANTOS, I.G.A. and RODRIGUES, G.G. Benthic macrofauna and the limnological parameters of a first-order stream in Atlantic Forest of Brazilian Northeast. Acta Limnologica Brasiliensis, 2014, 26(1), 26-34. http://dx.doi.org/10.1590/S2179975X2014000100005.

CUNICO, A.M., FERREIRA, E.A., AGOSTINHO, A.A., BEAUMORD, A.C. and FERNANDES, $R$. The effects of local and regional environmental factors on the structure of fish assemblages in the Pirapó Basin, Southern Brazil. Landscape and Urban Planning, 2012, 105(3), 336-344. http://dx.doi. org/10.1016/j.landurbplan.2012.01.002.

ELLIOTT, J.M. Ontogenetic shifts in drift periodicity and benthic dispersal in elmid beetles. Freshwater Biology, 2008, 53(4), 698-713. http://dx.doi. org/10.1111/j.1365-2427.2007.01927.x.

FERREIRA, K.M. Biology and ecomorphology of stream fishes from the rio Mogi-Guaçu basin, Southeastern Brazil. Neotropical Ichthyology, 2007, 5(3), 311-326. http://dx.doi.org/10.1590/S167962252007000300012

GILLETTE, D.P. Effects of variation among riffles on prey use and feeding selectivity of the orangethroat darter Etheostoma spectabile. American Midland Naturalist, 2012, 168(1), 184-201. http://dx.doi. org/10.1674/0003-0031-168.1.184.

GIMENEZ, B.C.G., LANSAC-TÔHA, F.A. and HIGUTI, J. Effect of land use on the composition, diversity and abundance of insects drifting in Neotropical streams. Brazilian Journal of Biology = Revista Brasileira de Biologia, 2015, 75(4, Suppl 1), S52-59. http://dx.doi.org/10.1590/15196984.03914. PMid:26602342.

GRIFFITHS, D. Prey availability and food of predators. Ecology, 1975, 56(5), 1209-1214. http://dx.doi. org/10.2307/1936161.

HELLAWELL, J.M. and ABEL, R.A. A rapid volumetric method for the analysis of the food of fishes. Journal of Fish Biology, 1971, 3(1), 29-37. http://dx.doi. org/10.1111/j.1095-8649.1971.tb05903.x.

HILL, J. and GROSSMAN, G.D. Home range estimates for three North American stream fishes. Copeia, 1987, 2, 376-380. http://dx.doi.org/10.2307/1445773.

LOPEZ CAZORLA, A., PETTIGROSSO, R.E., TEJERA, L. and CAMINA, R. Diet and food selection by Ramnogaster arcuata (Osteichthyes, Clupeidae). Journal of Fish Biology, 2011, 78(7), 2052-2066. http://dx.doi.org/10.1111/j.10958649.2011.02995.x. PMid:21651549.

MACARTHUR, R.H. and PIANKA, E.R. On optimal use of a patchy environment. American Naturalist, 1966, 100(916), 603-609. http://dx.doi. org/10.1086/282454.

MCCAFFERTY, W.P. Aquatic entomology. Sudbury: Jones and Barlett, 1981.

MELO, A.S. and FROEHLICH, C.G. Macroinvertebrates in Neotropical streams: richness patterns along a catchment and assemblage structure between 2 seasons. The North American Benthological Society, 2001, 20(1), 1-16. http:// dx.doi.org/10.2307/1468184.

MELO, C.E., MACHADO, F.A. and PINTO-SILVA, $V$. Feeding habits of fish from a stream in the savanna of Central Brazil, Araguaia Basin. Neotropical Ichthyology, 2004, 2(1), 37-44. http://dx.doi. org/10.1590/S1679-62252004000100006.

MERRITT, R.W. and CUMMINS, K.W. An introdution to the aquatic insects of North America. Dubuque: Kendall and Hunt, 1984.

MOYA, C., VALDOVINOS, C., MORAGA, A., ROMERO, F., DEBELS, P. and OYANEDEL, A. Patrones de distribución espacial de ensambles de macroinvertebrados bentónicos de un sistema fluvial Andino Patagónico. Revista Chilena de Historia Natural, 2009, 82(3), 425-442. http://dx.doi. org/10.4067/S0716-078X2009000300009.

NEVES, M.P., DELARIVA, L.R. and WOLFF, L.L. Diet and ecomorphological relationships of an endemic, species-poor fish assemblage in a stream in the Iguaçu National Park. Neotropical Ichthyology, 2015, 13(1), 245-254. http://dx.doi.org/10.1590/1982-022420140124 .

O'BRIEN, W.J. Predator-prey interactions of planktivorous fish and zooplankton. American Scientist, 1979, 67, 572-581.

R DEVELOPMENT CORE TEAM. Package 'vegan'. Community Ecology Package. Ordination methods, diversity analysis and other functions for community and vegetation ecologists [online]. Vienna: $\mathrm{R}$ Development Core Team, 2018 [viewed 08 Dec. 2018]. Available from: https://CRAN.R-project.org/package=vegan

REZENDE, C.F., MAZZONI, R., CARAMASCHI, E.P., RODRIGUES, D. and MORAES, M. Prey selection by two benthic fish species in 
the Mato Grosso stream, Saquarema-RJ, Brazil. Revista de Biología Tropical, 2011, 59(4), 16971706. http://dx.doi.org/10.15517/rbt.v59i4.3432. PMid:22208086.

RODRÍGUEZ-LOZANO, P., VERKAIK, I., MACEDA-VEIGA, A., MONROY, M., DE SOSTOA, A., RIERADEVALL, M. and PRAT, N. A trait-based approach reveals the feeding selectivity of a small endangered Mediterranean fish. Ecology and Evolution, 2016, 6(10), 3299-3310. http://dx.doi. org/10.1002/ece3.2117. PMid:27252834.

ROLLA, A.P.R., ESTEVES, K.E. and ÁVILA-DASILVA, A.O. Feeding ecology of a stream fish assemblage in an Atlantic Forest remnant (Serra do Japi, SP, Brazil). Neotropical Ichthyology, 2009, 7(1), 65-76. http://dx.doi.org/10.1590/S167962252009000100009.

SILVA, J.C., DELARIVA, R.L. and BONATO, K.O. Food-resource partitioning among fish species from a first-order stream in northwestern Paraná, Brazil. Neotropical Ichthyology, 2012, 10(2), 389-399. http:// dx.doi.org/10.1590/S1679-62252012005000008.

SOARES, B.E., ROSA, D.C.O., SILVA, N.C.S., ALBRECHT, M.P. and CARAMASCHI, É.P. Resource use by two eletric fishes (Gymnotiformes) of the National Forest Saracá-Taquera Oriximiná, Pará. Neotropical Ichthyology, 2017, 15(2), e160144. http://dx.doi.org/10.1590/1982-0224-20160144.

SOUZA, A.M., FOGAÇA, F.N.O., CUNICO, A.M. and HIGUTI, J. Does the habitat structure control the distribution and diversity of the Odonata fauna? Brazilian Journal of Biology $=$ Revista Brasileira de Biologia, 2015, 75(3), 598-606. http://dx.doi. org/10.1590/1519-6984.18213. PMid:26421772.
STATSOFT. Statistica for Windows (data analysis software system), version 7.1. Tulsa: Statsoft Inc., 2005.

THORP, J.H. and COVICH, A.P. Ecology and classification of North American freshwater invertebrates. London: Academic Press, 2010.

TÓfOli, R.M., ALVES, G.H.Z., HIGUTI, J., CUNICO, A.M. and HAHN, N.S. Diet and feeding selectivity of a benthivorous fish in streams: responses to the effects of urbanization. Journal of Fish Biology, 2013, 83(1), 39-51. http://dx.doi.org/10.1111/ jfb.12145. PMid:23808691.

UIEDA, V.S. and RAMOS, L.H.B. Distribuição espacial da comunidade de macroinvertebrados bentônicos em um riacho tropical (Sudeste do Brasil). Bioikos (Campinas), 2007, 21, 3-9.

UNIVERSIDADE ESTADUALDEMARINGÁ-UEM. NÚCLEO DE PESQUISAS EM LIMNOLOGIA, ICTIOLOGIA E AQUICULTURA - NUPÉLIA. Coleçôes [online]. Maringá: NUPÉLIA, 2018 [viewed 08 Dec. 2018]. Available from: https://specify. nupelia.uem.br/specify/

WORISCHKA, S., SCHMIDT, S.I., HELLMANN, C. and WINKELMANN, C. Selective predation by benthivorous fish on stream macroinvertebrates - The role of prey traits and prey abundance. Limnologica, 2015, 52, 41-50. http://dx.doi.org/10.1016/j. limno.2015.03.004.

Received: 18 June 2018 Accepted: 23 January 2019 